GEOGRAFICKÝ ČASOPIS / GEOGRAPHICAL JOURNAL 73 (2021) 1, 63-81

DOI: https://doi.org/10.31577/geogrcas.2021.73.1.04

\title{
METODIKA TVORBY MODELU DOSTUPNOSTI ÚZEMIA SLOVENSKA NA BÁZE DENNEJ INTENZITY AUTOMOBILOVEJ DOPRAVY S VYUŽITÍM GEOINFORMAČNÝCH NÁSTROJOV
}

\author{
Richard Stanek*, Dagmar Kusendová*, Marcel Horňák* \\ * Univerzita Komenského v Bratislave, Prírodovedecká fakulta, Katedra ekonomickej a sociálnej geografie, \\ demografie a územného rozvoja, Ilkovičova 6, 84215 Bratislava, Slovensko, \\ stanek13@uniba.sk,dagmar.kusendova@uniba.sk,marcel.hornak@uniba.sk
}

\begin{abstract}
Slovakia's territory accessibility model design methodology based on daily car-traffic intensity using geoinformation tools

The paper presents opportunities of a model of transport accessibility by individual road transport in the environment of geographic information systems (GIS). The paper presents both data sets and the GIS environment in which the model was designed. Particular attention is paid to the application of individual factors influencing driving speed within the road network, with a greatest emphasis on the changing traffic intensity during the day as one of the factors affecting the accessibility of cities. Four traffic intensity regimes were selected to identify differences. In the results section, the differences resulting from the model are shown on the pilot territory of the Slovak Republic using the isochrone method.
\end{abstract}

Key words: time accessibility, accessibility model, GIS, network analysis, Slovakia

\section{ÚVOD}

Automobilová doprava je v súčasnosti dominantným spôsobom prepravy osôb a nákladov v štátoch Európskej únie i na Slovensku. V krajinách strednej Európy prišlo k prudkému nárastu významu cestnej dopravy po zániku socialistických režimov v dôsledku reštrukturalizácie ekonomík a spoločenských zmien, vrátane liberalizácie trhov dopravy. Nastáva oslabenie verejného sektora a verejnej dopravy (Poliak et al. 2017 a Taylor a Ciechański 2020), narastá význam cestnej dopravy pri preprave nákladov i osôb (Marada et al. 2010, Horňák et al. 2013, Smieszek et al. 2013, Stepniak a Rosik 2013 a d'alší) a mení sa mobilitné správanie obyvatel'stva. Prichádza postupne $\mathrm{k}$ zlepšovaniu dostupnosti $\mathrm{v}$ dopravných siet'ach (Hudeček et al. 2011, Michniak 2014, Horák et al. 2015, Komornicki a Stępniak 2015, Mulíček et al. 2015, Halás a Kraft 2016, Šveda a Barlík 2018 a Pešek a Kraft 2019), ale i nárastu kongescií a rôznych konfliktov spôsobených rastúcou mierou automobilizácie domácností (Wiśniewski 2018, Horńák et al. 2019, Palúch et al. 2019, Gnap a Skřrivánek Kubíková 2020). V roku 2017 cestná (nákladná) doprava prepravila na území Slovenska 78 \% objemu všetkých nákladov, individuálna automobilová doprava $74 \%$ všetkých prepravených osôb a autobusová doprava d'alších 9 \% osôb (MDaV SR 2018), čo dokazuje signifikantnost' fenoménu cestnej dopravy $\mathrm{v}$ našej spoločnosti. Prichádza $\mathrm{k}$ zmene dynamiky mobilitných tokov v rámci denného, príp. týždenného rytmu (Ahas et al. 2010, Mulíček et al. 2015 a 2016 a Nemeškal et al. 2020), sledujeme nárast cyklických zmien v doprave, reflektujúcich dennú rytmiku spoločensko-ekonomických procesov, čo ovplyvňuje aktuálnu dostupnost' ciel'ov v reálnych dopravných siet’ach. To je jeden z námetov pre výskum tejto oblasti. 
V tejto súvislosti narastá význam skúmania fungovania cestnej siete a merania dostupnosti v nej, v súčasnom období najmä s využitím rôznych platforiem na báze nástrojov geografických informačných systémov (GIS). Štúdií, ktoré skúmajú dostupnost' v cestnej sieti Slovenska s rôznou mierou detailnosti, vzniklo viacero, napr. Kusendová (1996), Tolmáči (2002), Michniak (2003), Horňák (2005) a Michniak et al. (2015). Väčšina z nich hodnotí dostupnost' v cestnej sieti v „statickom“ režime, bez zohl'adnenia dynamických zmien dostupnosti v dôsledku meniacej sa intenzity dopravy na cestných komunikáciách v dennom rytme. Pri súčasnom raste intenzity dopravy je preto zohl'adnenie intenzity cestnej dopravy a jej dosahu na reálnu cestovnú rýchlost' námetom na výskum a priestorové modelovanie dostupnosti v cestnej sieti, čo bolo inšpiráciou pre náš príspevok.

Hlavným ciel'om príspevku je predstavenie metodiky tvorby modelu časovej dostupnosti individuálnou automobilovou dopravou v konkrétnom prostredí GIS s akcentom na dynamicky sa meniaci vstupný faktor - intenzitu dopravy. V závere prinášame konkrétnu ukážku vizualizácie výsledkov aplikácie tohto postupu na príklade dostupnosti Bratislavy v rámci územia Slovenskej republiky, pričom vyuŽívame štyri stavy časovej dostupnosti pri aplikácii štyroch stavov intenzity dopravy:

1 - stav priemerného počtu vozidiel na cestách za 24 hodín - priemerná denná intenzita dopravy,

2 - stav s nočnou intenzitou dopravy,

3 - stav s intenzitou dopravy počas dopravnej špičky,

4 - stav s intenzitou dopravy medzi dopravnými špičkami - intenzita počas dopravného sedla.

\section{KONCEPT DOSTUPNOSTI A VYUŽITIE GEOINFORMAČNÝCH NÁSTROJOV}

Hodnotenie dopravnej dostupnosti patrí medzi časté analýzy pri štúdiu dopravných sietí a infraštruktúry (Hoyle and Knowles 1992, Hudeček 2010 a Horák et al. 2019). Pojem dostupnost' je frekventovaný, avšak je t'ažké ho presne vyjadrit' alebo merat' (Gould 1969 a Michniak 2003). Existuje viac definícií tohto pojmu. Najpodrobnejšie sa prístupom k dostupnosti venovali Handy a Niemeier (1997), Baradaran a Ramjerdi (2001), Geurs a Ritsema van Eck (2001), alebo Geurs a van Wee (2004). Na meranie dostupnosti sa používa celý rad ukazovatel’ov (Križan 2007), chápanie dostupnosti môže byt' $\mathrm{v}$ závislosti od použitých parametrov pomerne rôznorodé. $\mathrm{V}$ našom príspevku budeme dostupnost' chápat' ako l'ahkost' dosiahnutia miesta alebo služby z ostatných miest, ktorá môže byt' meraná napr. prekonanou vzdialenost'ou, vynaloženými cestovnými nákladmi alebo časom trvania cesty (Clark 1990).Takémuto chápaniu dostupnosti bude zodpovedat' naša konštrukcia modelu časovej dostupnosti individuálnou automobilovou dopravou.

V súčasnosti sú GIS a ich geoinformačné nástroje súčast’ou výskumu dopravnej dostupnosti, použité boli v mnohých prácach (Geertman and Ritsema van Eck 1995, Apparicio et al. 2008, Martín et al. 2010, Benenson et al. 2011, Horák et al. 2015, atd'.). Dostupnost' miesta je možné v softvéroch GIS riešit' rôznymi spôsobmi. Proces zist'ovania závisí od zvoleného typu priestorovej separácie - fyzická, skutočná fyzická (v dopravnej sieti), časová či ekonomická vzdialenost' atd'. (Warakomska 1992). Podl'a typu priestorovej separácie je možné zvolit' postup 
v softvéroch GIS. Najjednoduchšou formou zist'ovania dostupnosti sú koncentrické vzdialenostné zóny, angl. buffer (de Jong and Ritsema van Eck 1996). V súčasnosti patria do výbavy softvérov GIS aj nástroje na analýzy dopravných problémov, resp. problémov siete a siet'ových vzdialeností, súhrnne označované ako siet'ová analýza. $\mathrm{K}$ jej nástrojom patria: hl'adanie najkratšej trasy medzi dvomi uzlami na sieti, problém obchodného cestujúceho (travelling salesman problem), vzdialenostné matice alebo nástroje riešiace lokalizáciu zariadenia. V prípade špecifických ukazovatel'ov výsledky získané prostredníctvom týchto nástrojov predstavujú vstup do daného výpočtu (O'Sullivan et al. 2000).

Zist'ovanie dostupnosti na základe hodnôt časovej vzdialenosti si vyžaduje tvorbu modelu dostupnosti. Modelovanie predstavuje základný koncept pre poznávanie systémov, existujú $\mathrm{k}$ nemu rôzne prístupy a $\mathrm{z}$ toho vyplývajúce rôzne klasifikácie (Horák et al. 2019). Presnost' modelu je daná presnost'ou vstupných dát. V prípade vzt'ahu modelu a GIS sa dá chápat' samotný GIS ako deskriptívny model alebo nástroj umožňujúci modelovanie reality - analytický model (Geertman a Ritsema van Eck 1995). Podl'a Halvu a Rábka (2012) je základom práce v GIS poznanie reality a na jej základe správne vytvorenie alebo zvolenie priestorových dát, ktoré predstavujú vierohodnú reprezentáciu reality. Nepresnosti vstupujúce do modelu sa nielen zachovávajú, ale môžu sa dokonca násobit' (Halva a Kliment 2009).

Softvéry GIS ponúkajú pre tvorbu modelu a analýzu dostupnosti ,,vektorovú“ aj „rastrovú“ formu, ktorá spočíva v tvorbe „frikčného“ povrchu (Juliao 1999 a Ahlström 2008). V príspevku sme pracovali s vektorovým a následne siet'ovým modelom, prezentujúcim cestnú siet'v prostredí GIS s vybranými atribútmi, na základe ktorých sa dá modelovat' časová vzdialenost' na sieti alebo na povrchu (Tykkyläinen 1981). Metódy vychádzajúce $z$ teórie grafov sú schopné hl'adat' najkratšie cesty v sieti transformovanej do grafu, ktorý predstavuje symbolickú reprezentáciu (dopravnej) siete a jej prepojení. Ide o topologickú reprezentáciu siete pomocou uzlov a hrán (Goodall 1987). Siet'ové analýzy pomáhajú analyzovat' vlastnosti rôznych komunikačných štruktúr v priestore, resp. sa využívajú na výpočty vzdialeností a ciest (alebo inej charakteristiky) medzi dvomi miestami (Comber et al. 2008).

Táto čast' príspevku detailne opisuje postup tvorby modelu dostupnosti z poskytnutého modelu cestnej siete a d’alších dátových podkladov. Kapitola obsahuje krátky opis použitého softvéru a dátových vstupov. Následne je upriamená pozornost' na geoinformačné nástroje a postupy použité na zostavenie modelu dostupnosti v prostredí softvéru GIS. Nakoniec uvádzame vizualizáciu výsledkov ako príklad aplikácie uvedenej metódy.

\section{POUŽITÝ SOFTVÉR A DÁTOVÉ PODKLADY}

$\mathrm{Na}$ analýzu a vizualizáciu bolo využité softvérové prostredie ArcGIS Desktop aplikácia ArcMap s rozšíreniami Spatial Analyst a Network Analyst. Práve extenzia Network Analyst umožňuje prostredníctvom nástroja Network Dataset využitie rôznych funkcií postavených na princípe siet'ových analýz. Network Dataset preberá atribúty z pôvodnej líniovej vrstvy, na základe ktorých sa zist'uje najmenej náročná trasa, tým vytvára možnosti využit’ rôzne vyjadrenia priestorovej separácie. Pracovali sme najmä s časovou vzdialenost’ou ohodnotenia hrán - líniových úsekov ciest. 
Prvú skupinu vstupných dát tvorili dáta vstupujúce priamo do konštrukcie cestného modelu pre siet'ové analýzy. Kl'účové boli dátové súbory poskytnuté odborom Cestnej databanky (CDB) Slovenskej správy ciest (SSC) predstavujúce referenčnú siet' cestných a miestnych komunikácií platnú k roku 2018 (model cestnej siete $\mathrm{v}$ rozsahu dial'nic, rýchlostných ciest, ciest I., II., III. triedy a niektorých miestnych komunikácií), platnost' dopravných značiek obmedzujúcich rýchlost' a sčítacie úseky s údajmi zo sčítania dopravy v roku $2015^{1}$. Do tejto skupiny dátových podkladov sme zaradili aj vrstvu budov na Slovensku z OpenStreetMap.org ${ }^{2}$ platnú $\mathrm{k}$ roku 2018, ktorou sme v identifikovali v GIS a vytvorili zastavané územia obcí. Druhú skupinu dát tvorila bodová vrstva reprezentujúca analyzované miesta/ lokality, v našom prípade obce SR. Na ich tvorbu sme využili portál geonames.org poskytujúci dáta poštových kódov s geokódovaním do zastavaných území obcí platné k roku $2018^{3}$. Polohové nepresnosti bodovej lokalizácie boli manuálnou editáciou upravené podl'a zdroja googlemaps.com. Výsledkom bola bodová vrstva s 2927 záznamami reprezentujúcimi centrum každej obce, v prípade Bratislavy a Košíc centrá mestských častí, z ktorých boli vybrané krajské mestá vrátane Bratislavy vo funkcii centier výpočtu. Poslednú, tretiu skupinu dátových podkladov tvorili vrstvy hraníc reprezentujúce územné a správne usporiadanie Slovenskej republiky. Tu sme využili geodatabázu Základnej bázy údajov pre geografický informačný systém $(Z B G I S ®)$ s vrstvami hraníc SR, krajov, okresov a obcí ${ }^{4}$ platných $\mathrm{k}$ roku 2018 (v príspevku bola použitá vrstva krajov).

\section{MODEL ČASOVEJ DOSTUPNOSTI}

$\mathrm{Na}$ zist'ovanie najkratšej vzdialenosti bolo treba naplnit' model cestnej siete časovými údajmi, čiže transformovat' cestnú vzdialenost' na čas. Transformáciu vzdialenosti na rýchlost', resp. čas riešilo viacero prác (napr. Brabyn a Skelly 2001, Peňáz 2005, Jánošíková 2007, Maier et al. 2007, Hudeček 2010, Kotavaara et al. 2011, Cojanu et al. 2012, Chen et al. 2018 a Horák et al. 2019). Autori aplikovali vybrané faktory ovplyvňujúce rýchlost', v niektorých prípadoch šlo len o odhad zníženia rýchlosti na danú hodnotu. Hudeček (2010) uvádza nasledujúce faktory ovplyvňujúce rýchlost' na cestnej komunikácii - trieda komunikácie, zastavanost' územia, šírka cesty, stav komunikácie, denná doba, stav vozového parku, pozdížny sklon, krivol'akost', ročné obdobie, nehodovost' a intenzita dopravy. Výber faktorov pre náš model bol ovplyvnený najmä disponibilitou dát. Najvýraznejším faktorom ovplyvňujúcim maximálnu rýchlost' na cestách je v našom modeli trieda komunikácie v kombinácii s faktorom zastavanosti územia, nasleduje platnost' dopravných značiek obmedzujúcich rýchlost' na cestných komunikáciách a intenzita dopravy v kombinácii so šírkou cesty, resp. počtom cestných pruhov. Zatial' čo prvé tri faktory sú stále, intenzita dopravy sa v priebehu dňa mení.

\footnotetext{
${ }^{1}$ Licenčná zmluva o poskytnutí súhlasu s používaním vybraných údajov centrálnej technickej evidencie pozemných komunikácií SR č. 707/2019/2100

C Model cestnej siete, Slovenská správa ciest, Cestná databanka 01.01.2019, Sčítacie úseky, Slovenská správa ciest 2015

${ }^{2}$ Licencia Open Data Commons Open Database License - ODbL

${ }^{3}$ Licencia Creative Commons Attribution 4.0 License

${ }^{4}$ ZBGIS ${ }^{\circledR}$, Úrad geodézie, kartografie a katastra Slovenskej republiky
} 
Základným dátovým súborom určujúcim funkčnost' modelu je referenčná siet' cestných a miestnych komunikácií. Tá v softvéri GIS vystupuje ako líniová vrstva, ktorej jednotlivé segmenty sú cestné úseky s korektne riešenou topológiou. Základnými požiadavkami na dátový súbor sú topologická korektnost' a vybrané charakteristiky - atribúty cestných komunikácií. Dva základné atribúty sú trieda komunikácie a atribút obojsmernosti, resp. jednosmernosti. Trieda komunikácie determinuje maximálnu rýchlost' určenú príslušným zákonom ${ }^{5}$. Preto bolo potrebné určit' úseky prechádzajúce zastavaným územím obce pomocou dátového súboru reprezentujúceho zastavané územie (ZU) obce. Túto vrstvu sme získali z vrstvy budov z OSM prostredníctvom geoprocessing nástrojov v programe ArcGIS. Základom tohto procesu spracovania vstupných geografických dát bol nástroj Buffer (Analysis Tools: Analysis), teda vytvorenie koncentrickej zóny vo vzdialenosti $100 \mathrm{~m}$ okolo budov (obr. 1).

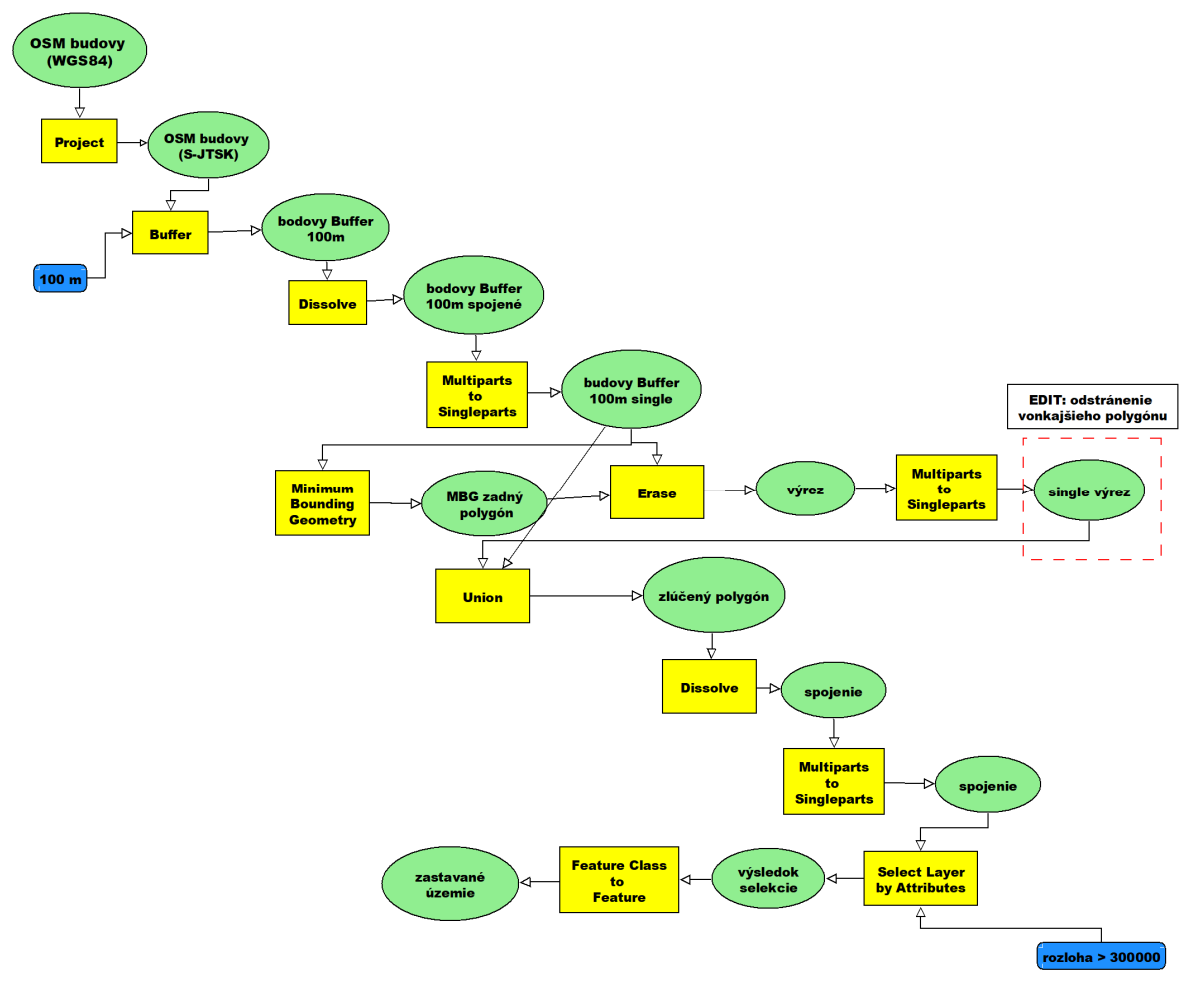

Obr. 1. Schéma postupu vytvorenia zastavaných území - Model Builder (ArcMap) Vlastné spracovanie.

Po vytvorení polygónovej vrstvy zastavaných území boli úseky v zastavanom území obcí v prostredí GIS určené sériou viacerých nástrojov pre prácu s vrstvami (obr. 2), to umožnilo v databáze rozlíšit’ tieto úseky hodnotou atribútu (obr. 3).

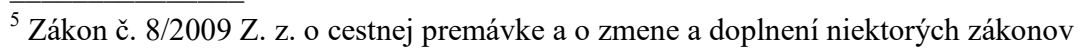




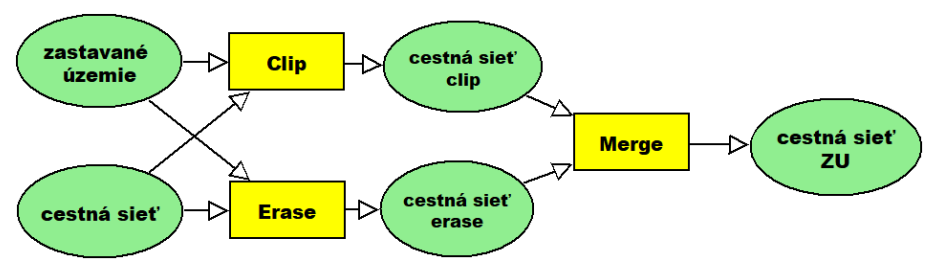

Obr. 2. Schéma postupu vyčlenenia cestných úsekov nachádzajúcich sa v zastavanom území a mimo neho - Model Builder (ArcMap)

Vlastné spracovanie.

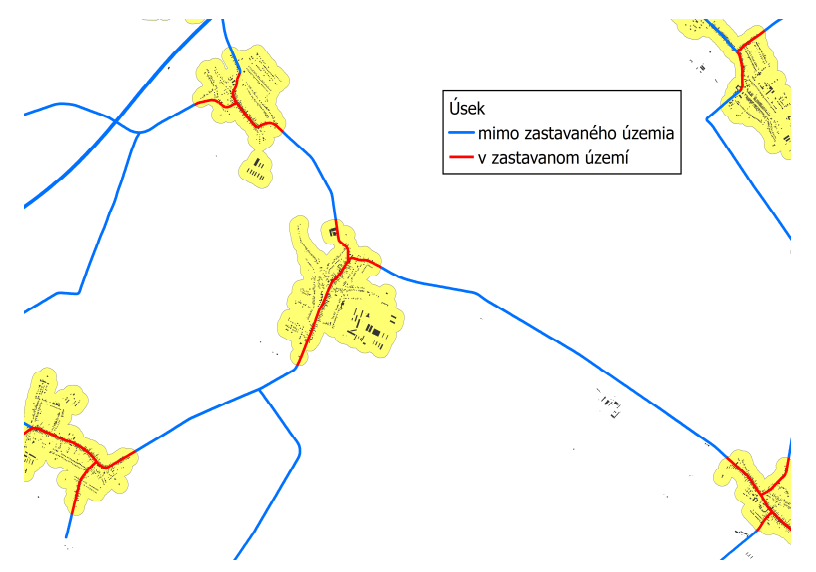

Obr. 3. Ukážka rozdelenia úsekov na základe prítomnosti/neprítomnosti zastavaného územia - ArcMap

Vlastné spracovanie.

Platnost' dopravných značiek obmedzujúcich rýchlost' je reprezentovaná líniovou vrstvou, kde platnost' úseku zodpovedá jednému segmentu vrstvy. V prípade cestných úsekov bez obmedzení daných dopravnou značkou bola úsekom priradená hodnota zodpovedajúca triede cestnej komunikácie (maximálna povolená rýchlost'). Špecifikom vrstvy je grafické riešenie, kde každý smer komunikácie prezentuje samostatná línia. Úseky s platnost’ou dopravných značiek obmedzujúcich rýchlost' nepokrývali celú referenčnú siet', chýbali údaje za miestne komunikácie, ktoré nemá v správe SSC. Pre prepojenie línií reprezentujúcich dopravné značky obmedzujúce rýchlost' pre oba smery bol použitý nástroj Spatial Join (Analysis Tools: Overlay). K ciel'ovej vrstve (referenčná siet' cestných a miestnych komunikácií) boli pripojené obe líniové vrstvy, a tak sme v našej databáze doplnili dva nové atribúty určujúce rýchlost' na cestnom úseku pre každý smer.

Siet'ové rozšírenie ArcGIS - Network Analyst ponúka možnost' tzv. časovej penalizácie pri odbočovaní. Penalizácia odbočenia je stanovená uhlom, pod ktorým sa napájajú alebo krížia cesty. Následné časové straty sa nastavujú pre každý smer odbočenia (vrátane kríženia ciest) s ohl'adom na hierarchiu cesty. V našom modeli sme ponechali pôvodné nastavenie odbočení ponúkané softvérom - Global Turns.

Údaje o intenzite dopravy sú z celoštátneho sčítania dopravy z roku 2015. Výhodami tohto cenzu bol rozsah (celé územie Slovenskej republiky), periodicita 
(každých pät' rokov) a priestorová presnost' (daná sčítacím úsekom). Ale má i nevýhody, napr. nemôže odlíšit' tranzitnú dopravu od regionálnej/miestnej, nezist'uje sa obsadenost' vozidla ani počiatok a ciel' cesty vozidla (Viturka 1981, Kraft et al. 2014 a Horňák a Kraft 2015).

Intenzita dopravy v sieti dial'nic, rýchlostných ciest, ciest I. a II. triedy a vybranej sieti ciest III. triedy je vyjadrená ako priemerná denná intenzita dopravy na danom cestnom úseku oboma smermi a zahŕňa všetky kategórie vozidiel. Sčítanie dopravy sa realizuje na tzv. sčítacích úsekoch cestných komunikácií ${ }^{6}$, za ktoré bol poskytnutý líniový vektorový dátový súbor, kde jednotlivé segmenty tvoria sčítacie úseky. Táto vrstva nie je topologicky korektná, chýbajú úseky najmä na kríženiach ciest, viaceré úseky na cestách III. triedy a neobsahuje žiadne úseky miestnych komunikácií (obr. 4).

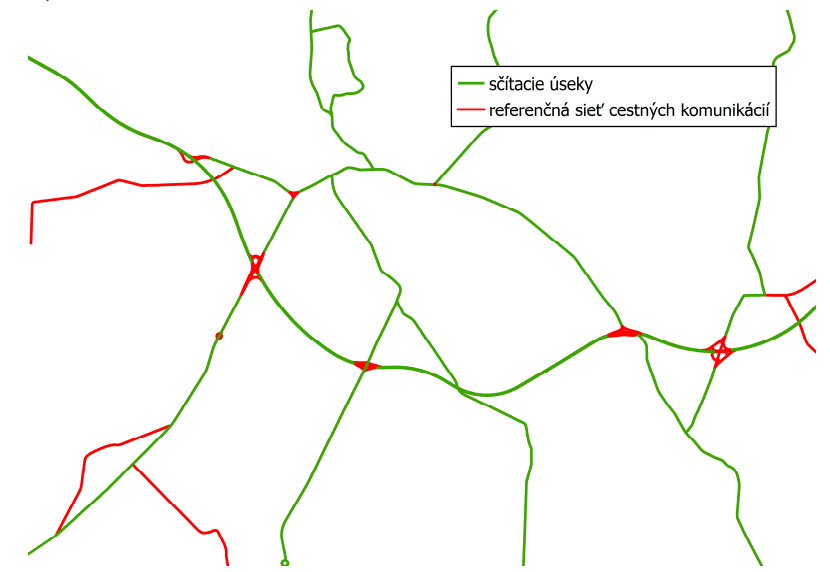

Obr. 4. Ukážka vrstvy sčítacích úsekov, geometrická nezhodnost’ s modelom cestnej siete v prostredí ArcMap

Vlastné spracovanie

Na včlenenie údajov o intenzite dopravy do všetkých úsekov referenčnej siete boli dopočítané hodnoty intenzity pre miesta bez údajov metódou priestorovej interpolácie, ktorej predchádzala tvorba reprezentatívnych bodov nad líniovou vrstvou pomocou autorského skriptu s intervalom $2 \mathrm{~km}$, čo predstavuje dostatočné husté vstupné bodové pole pre interpoláciu. Nástrojom Spatial Join (Analysis Tools: Overlay) boli prenesené hodnoty dopravnej intenzity z línií do bodov, z ktorých bola možná interpolácia do geografického priestoru na báze metódy Kriging Ordinary (Spatial Analyst Tools: Interpolation), vypočítavajúcej váhu pre vstupné body zo semivariogramov (Webster et al. 1994, Balabdaoui et al. 2001 a Cai et al. 2006). Takto sme získali novú súvislú rastrovú vrstvu s interpolovanými hodnotami intenzity dopravy (obr. 5).

$\mathrm{Z}$ rastra sme hodnoty intenzity dopravy doplnili do úsekov upravenej referenčnej siete komunikácií v prostredí ArcGIS (obr. 6).

\footnotetext{
${ }^{6}$ Sčítanie dopravy - SSC (2015)
} 


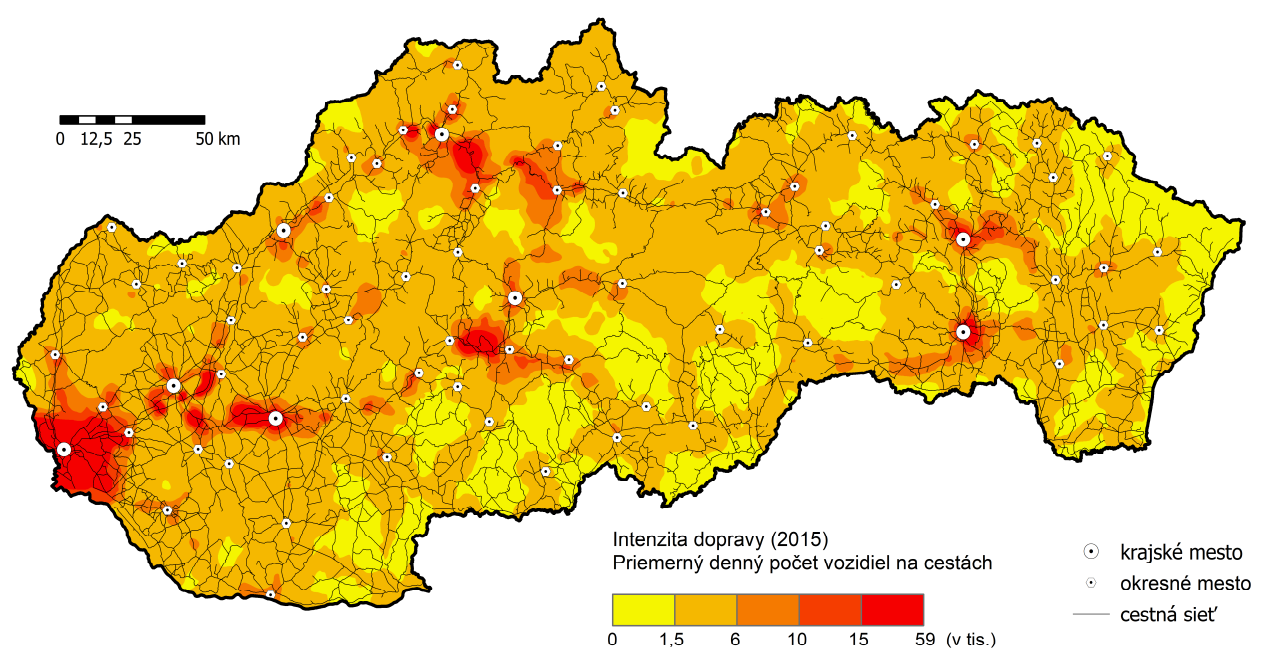

Obr. 5. Interpolácia intenzity dopravy v roku 2015

Zdroj: ZBGIS®, Úrad geodézie, kartografie a katastra Slovenskej republiky, Sčítacie úseky, Slovenská správa ciest (2015).

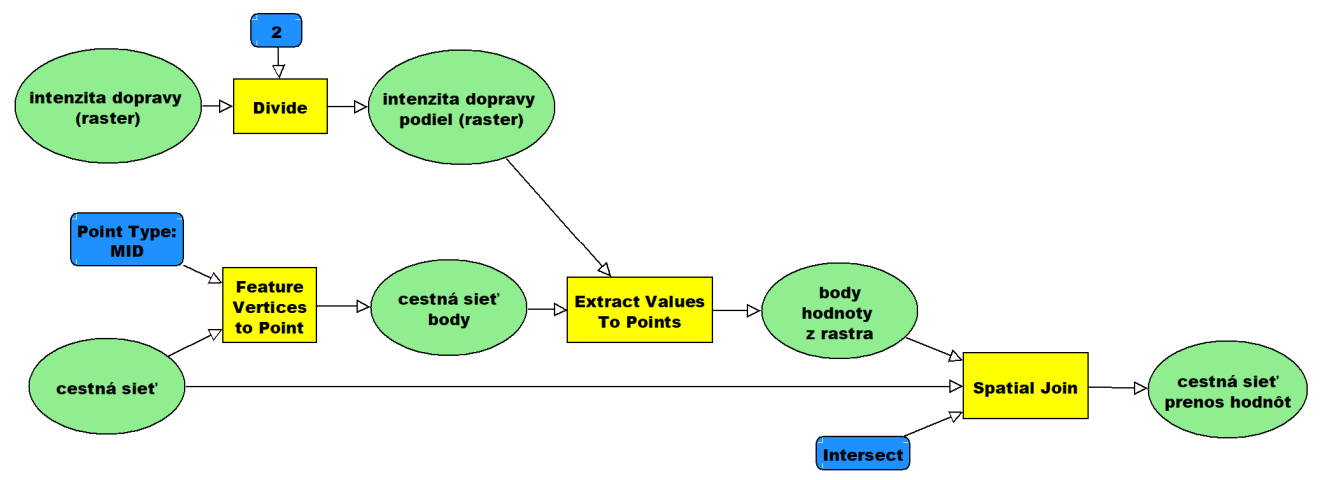

Obr. 6. Schéma postupu včlenenia hodnôt intenzity dopravy do cestnej siete - Model Builder (ArcMap)

Vlastné spracovanie.

Pri aplikácii vplyvu intenzity dopravy na rýchlost' bolo potrebné doplnit' údaje o počte pruhov na jednotlivých cestných úsekoch z portálu CDB. Úsekom bez hodnoty sme priradili jeden jazdný pruh na každý smer. Intenzita dopravy bola rozpočítaná na počet pruhov, číže hodnota intenzity v úseku bola vydelená počtom pruhov pre daný smer.

Aby sme získali intenzity dopravy vo vybraných časových rezoch dňa, bol potrebný rozklad celkovej hodnoty intenzity. Rozklad hodnoty sme určili na základe krivky priebehu intenzity dopravy (obr. 7) počas dňa, ktorá vznikla spriemerovaním typických kriviek intenzity dopravy počas pracovných dní (MDVRR 2015). Ako sme už v úvode uviedli, pracovali sme so štyrmi stavmi intenzity dopravy: 
1 - priemerná intenzita dopravy: hodnota bola určená ako počet vozidiel v cestnom pruhu podelená hodnotou 24 ,

2 - nočná intenzita dopravy: hodnota bola určená ako $0,5 \% \mathrm{z}$ počtu vozidiel $\mathrm{v}$ cestnom pruhu,

3 - sedlová intenzita dopravy: hodnota bola určená ako $5 \%$ z počtu vozidiel $\mathrm{v}$ cestnom pruhu,

4 - špičková intenzita dopravy: hodnota bola určená ako $10 \%$ z počtu vozidiel v cestnom pruhu.

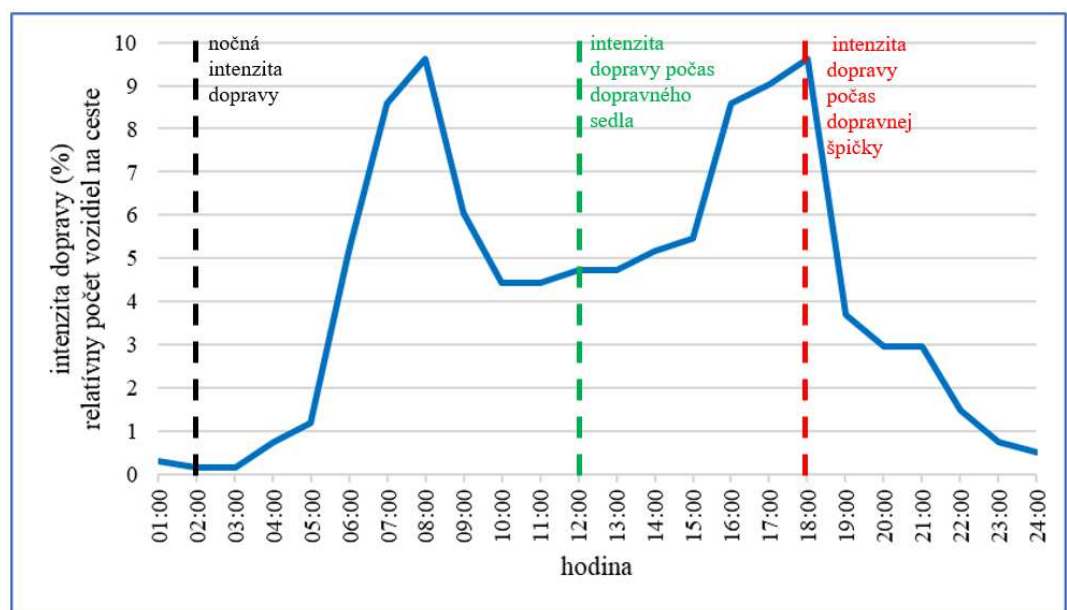

Obr. 7. Aproximovaný priebeh intenzity dopravy počas dňa (priemer pracovné dni)

Zdroj: MDVRR (2015), vlastné spracovanie.

Po pridelení hodnôt pre každý časový rez sme určili vplyv intenzity dopravy na rýchlost' na základe funkčnej úrovne dopravy (FÚ), ktorá je základným kritériom kvality ponúkanej obsluhy na pozemnej komunikácii. FÚ je určená stupňom jazdných možností, ktoré pozemná komunikácia poskytuje vozidlám a je rozdelená do šiestich úrovní $(\mathrm{A}-\mathrm{F})$ pohybu dopravy na základe počtu prejdených vozidiel na jednom jazdnom pruhu za hodinu. Pre každú úroveň je známa približná hodnota (resp. interval) počtu prejdených vozidiel na danom pruhu za hodinu, okrem úrovne F, ktorá reprezentuje rozpad dopravného prúdu pri dopravných nehodách a iných situáciách generujúcich kongescie (MDVRR 2015). Ked’že bol známy rad piatich hodnôt, na základe regresnej analýzy bola dopočítaná hodnota rýchlosti pre každú hodnotu intenzity dopravy. Rýchlost'v modeli vystupuje ako násobok maximálnej rýchlosti. To umožnilo metódu aplikovat' na rôzne triedy komunikácií. Intenzita dopravy bola nezávislá hodnota (x), a naopak rýchlost' závislá (y) predpovedaná hodnota. Pre určenie rýchlostí sme využili exponenciálny regresný model, aby sme zamedzili mínusovým hodnotám v prípade použitia lineárnej regresie pri extrémne vysokých hodnotách intenzity dopravy na niektorých úsekoch. Pre určenie exponenciálnej krivky sme okrem piatich zadaných hodnôt doplnili aj hraničné hodnoty extrémov, aby sme určili minimálnu a maximálnu hodnotu rýchlosti (obr. 8). 


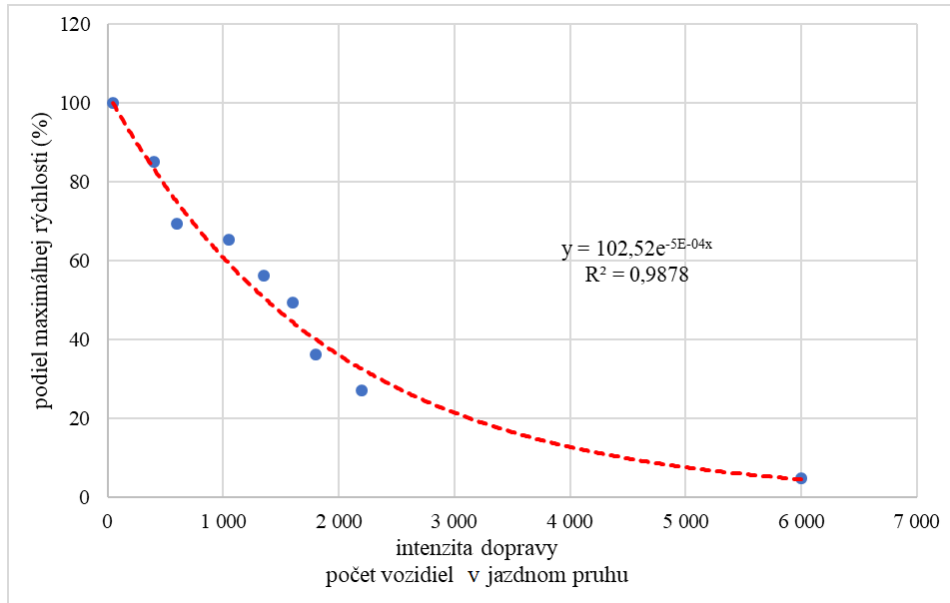

Obr. 8. Určenie rýchlostí na základe intenzity dopravy

Vlastné spracovanie.

Na základe regresnej rovnice sme určili percentuálny podiel rýchlosti pre každú hodnotu zo štyroch stavov intenzity dopravy. Špecifikom bol stav nočnej intenzity dopravy, kde bolo zníženie rýchlosti z maximálnej možnej rýchlosti takmer nulové. Preto sme sa rozhodli násobok nočnej intenzity dopravy určit' konštantne na všetkých úsekoch hodnotou 0,9 , t. j. 90 \% z maximálnej rýchlosti určenej triedou komunikácie alebo dopravnou značkou.

Rýchlost' bola do tohto kroku určená triedou komunikácie, polohou voči zastavanému územiu alebo dopravnou značkou obmedzujúcou rýchlost'. Túto rýchlost' sme vynásobili percentuálnymi podielmi z regresnej krivky, tým sme dostali rýchlost' pre každý segment vrstvy v každom reze intenzity dopravy. Do grafu pre siet'ovú analýzu stačilo prepočítat' na základe vzt'ahu rýchlosti $(v)$ a dížky cestnej komunikácie $(s)$ výsledný čas $(t)$, ktorý sme určovali v minútach (1).

$$
t[\min ]=\frac{s[\mathrm{~km}]}{v\left[\frac{\mathrm{km}}{h}\right]} \times 60,
$$

kde $t$ je výsledný čas $\mathrm{v}$ minútach, $s$ je dráha $\mathrm{v}$ kilometroch a $v$ je rýchlost’ $\mathrm{v}$ kilometroch za hodinu.

\section{VIZUALIZÁCIA VÝSLEDKOV NA PRÍKLADE DOSTUPNOSTI BRATISLAVY Z ÚZEMIA SLOVENSKA}

Príspevok je zameraný najmä metodicky na použitie geoinformačných nástrojov v prostredí GIS, takže výsledky slúžia len na ukážku rozdielov použitia jednotlivých dostupností. Na vizualizáciu výsledkov sme použili mapy dostupnosti (accessibility maps). Pomocou nástroja Service Areas (Network Analyst Tools: Analysis) sme vytvorili vzdialenostné zóny (izochróny) pre všetky štyri stavy intenzity dopravy (obr. 9). Miestom, ktorého dostupnost' sa počítala, bolo mesto Bratislava s tým, že celé územie Slovenskej republiky bolo rozdelené do zón dostupnosti s hodinovými intervalmi. 
a)

b)

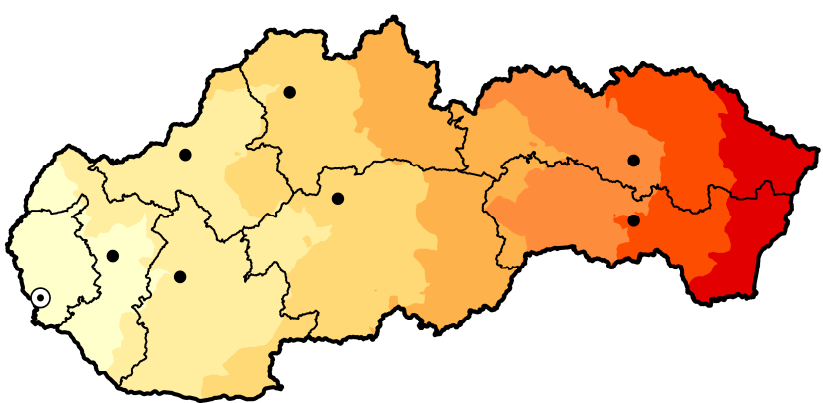

c)

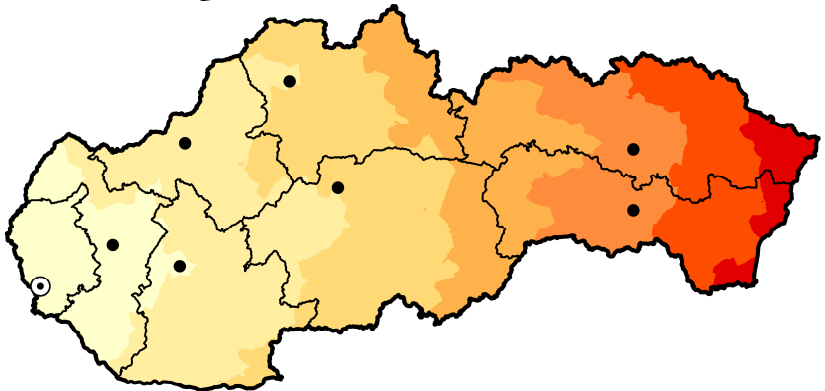

d)
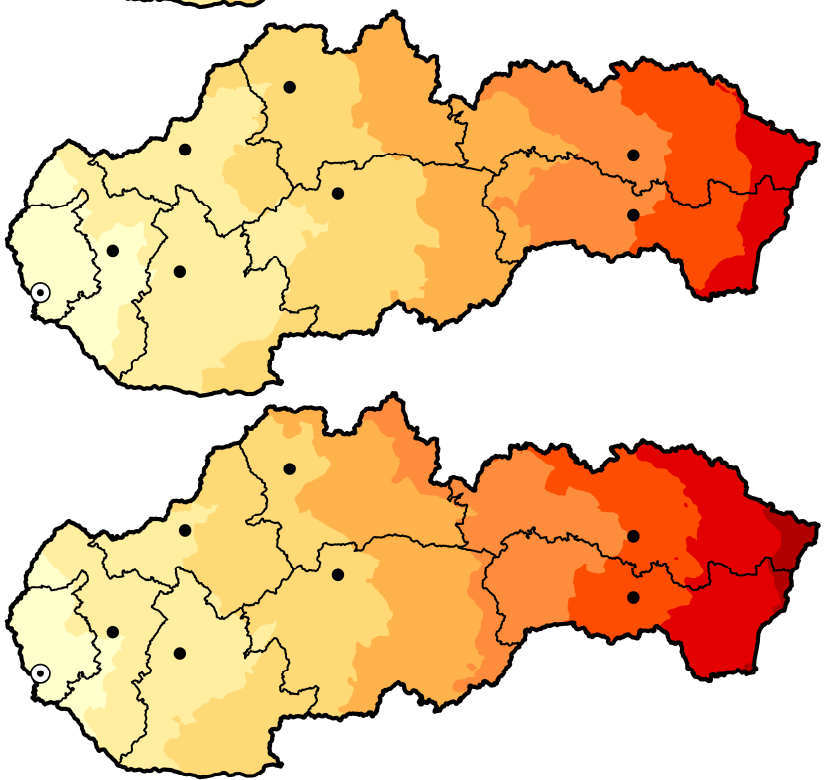

$0 \longdiv { 2 5 \quad 5 0 }$

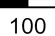

50

Vzdialenostné zóny (min)
$\odot$ Bratislava $\square$ hranica SR
- krajské mesto $\square$ krajská hranica

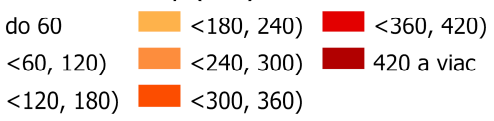

Obr. 9. Časová dostupnost' Bratislavy

a) - počas priemernej intenzity dopravy (24-hodinový priemer), b) - počas nočnej intenzity dopravy, c) - počas sedlovej intenzity dopravy, d) - počas špičkovej intenzity dopravy. Zdroj: ZBGIS®, Urad geodézie, kartografie a katastra Slovenskej republiky. 
$\mathrm{Na}$ obr. 9 je viditel'ný vplyv intenzity dopravy, aplikovaný naším postupom, na rýchlost' pohybu automobilov po cestných komunikáciách, ktorá ovplyvňuje aj výslednú dostupnost' miest $\mathrm{v}$ sieti. Na všetkých štyroch stavoch sú viditel'né podobné kontúry kopírujúce najdôležitejšie cestné komunikácie (dial'nice a rýchlostné cesty), ktoré dostupnost' výrazne ovplyvňujú. Logicky najväčšie rozdiely sa ukazujú medzi stavmi s nočnou a špičkovou intenzitou dopravy, pri ktorej vzniká na krajnom východe SR vzdialenostná zóna nad 420 minút.

Podrobnejšie je možné rozdiely sledovat' na obr. $10 \mathrm{~s}$ kvantifikáciou rozdielov prostredníctvom troch ukazovatel'ov: vel'kosti plochy, počtu obcí a počtu obyvatel'ov v daných časových zónach. Všetky tri grafy vykazujú podobné znaky. Uvedené výsledky sú ovplyvnené tvarom územia Slovenskej republiky, sídelnou štruktúrou a vel'kost'ou jednotlivých obcí. Vel'kost' rozlohy a najmä počet obcí sú v prvom intervale zastúpené oproti nasledujúcim dvom výrazne menej. Najväčšie rozdiely sú medzi stavmi s nočnou intenzitou dopravy a špičkovou intenzitou dopravy.

V prípade počtu obyvatel'ov je podiel obyvatel'ov v jednotlivých intervaloch na celkovej populácii odlišný od podielov na rozlohe alebo počte obcí. Počas dopravnej špičky je v tomto intervale dostupný takmer celý Bratislavský kraj vrátane hlavného a najväčšieho mesta Bratislavy. Komentovat' budeme opät' najmä porovnanie s nočnou intenzitou dopravy, kde je okrem Bratislavského kraja dostupný aj Trnavský kraj, ale tiež krajské mesto Nitra. V prípade špičkovej intenzity dopravy dosiahne za menej ako hodinu hlavné mesto menej než 750000 obyvatel'ov, kým pri nočnej intenzite takmer 1300000 .

Druhý a tretí interval vykazujú opät' podobné znaky naprieč všetkými tromi ukazovatel'mi. Do druhého intervalu spadá pomerne rozsiahle územie, pri nočnej intenzite dopravy sú v tomto intervale aj krajské mestá Žilina a Banská Bystrica. Značná priestorová podobnost' zóny s priemernou intenzitou dopravy a zóny so sedlovou intenzitou dopravy determinuje aj vel'kú podobnost' všetkých troch ukazovatel'ov $\mathrm{v}$ tomto intervale. Vzt'ah medzi intervalmi $\mathrm{v}$ jednotlivých rezoch dopravy je dobre viditel'ný pri pohl'ade na ukazovatele v dopravnej špičke, v druhom intervale je početnost' vo všetkých ukazovatel'och výrazne nižšia než v ostatných rezoch intenzity dopravy, v tret'om intervale je početnost' naopak najvyššia vo všetkých ukazovatel'och.

Predposledný siedmy interval (vzdialenost' šest' až sedem hodín) sa vyznačuje najmä väčšou rozlohou, početnost'ou obcí aj počtom obyvatel'ov v prípade špičkovej intenzity dopravy oproti ostatným intenzitám. Dôvodom je, že v špičkovej intenzite táto časová zóna pokrýva ovel'a väčšie územie než v ostatných intenzitách. To sa ešte viac odráža v počte obcí, ked' táto zóna pokrýva výraznú čast' Prešovského kraja s vel'kým množstvom obcí s malou populáciou. Posledný, ôsmy interval sa vytvára len počas špičkovej intenzity dopravy a pokrýva krajný východ Slovenskej republiky, zóna je priestorovo málo rozsiahla len s 31 obcami s celkovým počtom obyvatel'ov menším než 14000. 

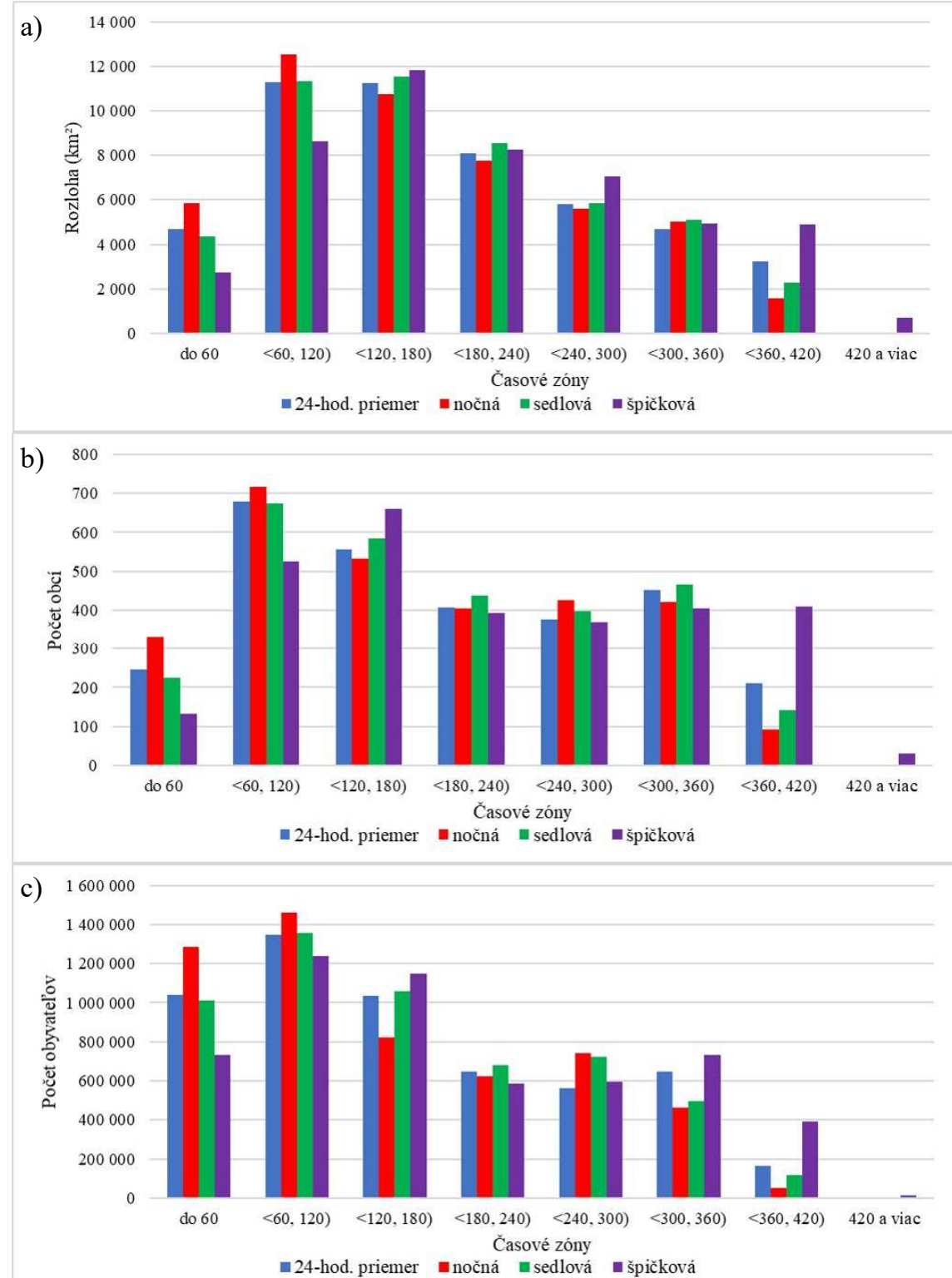

Obr. 10. a) - Porovnanie dostupnej rozlohy $\left(\mathrm{km}^{2}\right)$ časových zón podla jednotlivých rezov intenzity dopravy, b) - Porovnanie dostupného počtu obcí (a mestských častí Bratislavy a Košíc) podl'a jednotlivých rezov intenzity dopravy, c) - Porovnanie dostupného počtu obyvatel'ov podl'a jednotlivých rezov intenzity dopravy

\section{ZÁVER}

V súčasnosti ponúkajú softvéry GIS široké možnosti pre analýzy dostupnosti. Program ArcGIS Desktop a jeho rozšírenie Network Analyst patrí k najkomplexnejším riešeniam, umožňuje používatel'om vlastnú tvorbu siet'ového modelu a po- 
skytuje nástroje na jeho následne použitie a analýzu. Siet'ové rozšírenie umožňuje zohl'adnit' rôzne faktory pri budovaní modelu dostupnosti: intenzita dopravy, trieda komunikácie, obmedzujúce alebo smerové značenie, zákazy odbočenia a d'alšie. Pre všetky tieto faktory je treba mat' dostupné dáta $\mathrm{v}$ požadovaných formátoch a dátových štruktúrach. Náš príspevok je zameraný na tvorbu modelu z dát, ktoré nie sú priamo určené a pripravené na vstup do takéhoto modelu.

Za hlavný prínos príspevku považujeme opis procesu integrácie jednotlivých dátových vstupov, vyriešenie spojenia pôvodného dátového súboru reprezentujúceho sčítacie úseky s intenzitou dopravy a modelu cestnej siete, rozklad intenzity dopravy a jej aplikáciu na rýchlost' pri výpočte výslednej časovej dostupnosti. Príspevok ponúka konkrétne riešenie postupu tvorby modelu dostupnosti, ktoré pre naše územie doposial' nebolo použité. Model má parametre stanovené na základe konkrétneho funkčného vzt’ahu pre jednotlivé typy komunikácií pri aplikácii vybraných faktorov. Model bol tiež porovnaný s integrovaným modelom v ArcGIS Online, ktorý napriek možnostiam nastavenia dátumu a času - t. j. započítania aktuálnej dopravy na cestách - nevykazuje výrazné zmeny.

Medzi nevýhody modelu patria možné nepresnosti vzniknuté v jednotlivých parciálnych operáciách, ktorými bola priestorová interpolácia, aproximovanie rozloženia intenzity dopravy $\mathrm{v}$ priebehu dňa, exponenciálna regresná krivka a na jej základe odhad rýchlosti. Ide o úkony generujúce možné nepresnosti, ktoré sa v priebehu procesu môžu sčítavat' alebo násobit', ale nemali by mat' výrazný vplyv na výsledky. Nevýhodou modelu je tiež fakt, že nezohl'adňuje časové hl'adisko pri prekonávaní cesty, ked’že sú nastavené štyri rezy intenzity dopravy a na jej základe vypočítaná časová vzdialenost'. V prípade dlhých ciest model nezohl'adňuje čas strávený cestou, a teda možnú zmenu intenzity (posun do d’alšieho rezu) na konečnom mieste cesty. Pre model zohl'adňujúci trvanie cesty by sme však potrebovali „živé“ dáta pre každý cestný úsek.

Napriek uvedeným nevýhodám má podl’a nás model viacero kladov, ktorými sú: pokrytie celého územia Slovenska (predznačené územným rozsahom vstupných dát) a presne stanovené podmienky výpočtu rýchlosti a času s možnost'ou úpravy niektorých parametrov (napr. exponenciálnej regresnej krivky pri určení rýchlostí). Za najväčšiu výhodu modelu považujeme jeho nezávislost’ na použití konkrétneho softvéru. Tým, že takmer všetky použité nástroje a aplikované geoinformačné operácie sme realizovali priamo s vrstvami v univerzálnom súborovom formáte *.SHP, možno model použit' $v$ rôznych softvéroch GIS a využit' tak plný potenciál komplementárnych nástrojov jednotlivých softvérov založených na siet'ových analýzach. Model dostupnosti bol okrem softvéru ArcGIS a jeho siet'ovej extenzie počítaný aj v dvoch softvéroch: QGIS $3.4^{7}$ a v ňom pridaných zásuvných moduloch, SuperGIS Desktop $10.1^{8} \mathrm{~s}$ jeho extenziou Network Analyst. Dá sa realizovat' napr. aj v siet'ovom rozšírení softvéru pgRouting pre PostgreSQL'.

Možnosti softvérov GIS v kombinácii s dostupnými údajmi ponúkajú aj d’alšie zlepšenia, ktoré by mohli priniest' zvýšenie presnosti modelu. Patrí k nim napr. zaradenie nadmorských výšok a z nich vyplývajúci pozdížny sklon cestných úsekov,

\footnotetext{
${ }^{7}$ QGIS - Dostupné na: https://qgis.org/en/site/

${ }^{8}$ SuperGIS Desktop Network Analyst - Dostupné na: https://www.supergeotek.com/index.php/products_network analyst/

${ }^{9}$ pgRouting - Dostupné na: https://pgrouting.org/
} 
krivol'akost' cestných komunikácií, stav povrchu cestného úseku alebo zákazy odbočenia. Dalšie spresnenie modelu by mohlo priniest' rozšírenie modelu cestnej siete o úseky nachádzajúce sa v okolitých krajinách v blízkosti hraníc.

\section{LITERATÚRA}

AHAS, R., AASA, A., SILM, S., TIRU, M. (2010). Daily rhythms of suburban commuters' movements in the Tallinn metropolitan area: Case study with mobile positioning data. Transportation Research Part C: Emerging Technologies, 18, 45-54. DOI: https:// doi.org/10.1016/j.trc.2009.04.011.

AHLSTRÖM, A. (2008). Accessibility, poverty and land cover in Hambantota district, Sri Lanka: incorporating local knowledge into a GIS based accessibility model: a minor field study. Lunds universitets Naturgeografiska institution-Seminarieuppsatser, 144 (Lund University), [Online]. Dostupné na: https://lup.lub.lu.se/student-papers/search/ publication/1895471 [cit: 6-11- 2020].

APPARICIO, P., ABDELMAJID, M., RIVA, M., SHEARMUR, R. (2008). Comparing alternative approaches to measuring the geographical accessibility of urban health services: Distance types and aggregation-error issues. International Journal of Health Geographics, 7, 7. DOI: https://doi.org/10.1186/1476-072X-7-7.

BALABDAOUI, F., BOCQUET-APPEL, J. P., LAJAUNIE, C., IRUDAYA RAJAN, S. (2001). Space-time evolution of the fertility transition in India, 1961-1991. International Journal of Population Geography, 7, 129-148. DOI: https://doi.org/10.1002/ ijpg.213.

BARADARAN, S., RAMJERDI, F. (2001). Performance of accessibility measures in Europe. Journal of Transportation and Statistics, 4(2/3), 31-48.

BENENSON, I., MARTENS, K., ROFÉ, Y., KWARTLER, A. (2011). Public transport versus private car GIS-based estimation of accessibility applied to the Tel Aviv metropolitan area. The Annals of Regional Science, 47, 499-515. DOI: https:// doi.org/10.1007/s00168-010-0392-6.

BRABYN, L., SKELLY, C. (2001). Geographical access to services, health (GASH): modelling population access to New Zealand public hospitals. In Proceedings: Thirteenth Annual Colloquium of the Spatial Information Research Centre, 2(5), 163-174. DOI: https://doi.org/10.1186/1476-072X-1-3.

CAI, Q., RUSHTON, G., BHADURI, B., BRIGHT, E., COLEMAN, P. (2006). Estimating small-area populations by age and sex using spatial interpolation and statistical inference methods. Transactions in GIS, 10, 577-598. DOI: https://doi.org/10.1111/j.14679671.2006.01013.x.

CLARK, A. N. (1990). The new Penguin dictionary of geography. Harmondsworth (Penguin Books).

COJANU, V., DOBRE, R., PĂTRU-STUPARIU, I. (2012). The accessibility buffer - A basic GIS tool in determining the competitive potential index. Procedia Environmental Sciences, 14, 237-246. DOI: https://doi.org/10.1016/j.proenv.2012.03.023.

COMBER, A., BRUNSDON, C., GREEN, E. (2008). Using a GIS-based network analysis to determine urban greenspace accessibility for different ethnic and religious groups. Landscape and Urban Planning, 86, 103-114. DOI: https://doi.org/10.1016/ j.landurbplan.2008.01.002.

De JONG, T., RITSEMA Van ECK, J. R. (1996). Location profile-based measures as an improvement on accessibility modelling in GIS. Computers, Environment and Urban Systems, 20(3), 181-190. DOI: https://doi.org/10.1016/S0198-9715(96)00013-0.

GEERTMAN, S. C., RITSEMA Van ECK, J. R. (1995). GIS and models of accessibility potential: an application in planning. International Journal of Geographical Information Systems, 9, 67-80. DOI: https://doi.org/10.1080/02693799508902025.

GEURS, K. T., RITSEMA Van ECK, J. R. (2001). Accessibility measures: review and applications. Evaluation of accessibility impacts of land-use transportation scenarios, and 
related social and economic impact. Utrecht (Utrecht University, Urban Research Centre).

GEURS, K. T., Van WEE, B. (2004). Accessibility evaluation of land-use and transport strategies: review and research directions. Journal of Transport Geography, 12, 127-140. DOI: https://doi.org/10.1016/j.jtrangeo.2003.10.005.

GNAP, J., SKŘIVÁNEK KUBÍKOVÁ, S. (2020). Possible effects of lacking parking areas for road freight transport on logistics and transport safety. Transportation Research Procedia, 44, 53-60. DOI: https://doi.org/10.1016/j.trpro.2020.02.009.

GOODALL, B. (1987). Dictionary of human geography. $1^{\text {st }}$ ed. London (Penguin Books).

GOULD, P. R. (1969). Spatial diffusion. Resource Paper No. 4. Washington, D.C. (Association of American Geographers).

HALÁS, M., KRAFT, S. (2016). Modelling and prediction of long-distance traffic flows through the example of road transport in the Czech Republic. Scottish Geographical Journal, 132, 103-117. DOI: https://doi.org/10.1080/14702541.2015.1084029.

HALVA, A., RÁBEK, J. (2012). Overenie kvality priestorových dát. In Grešová, L., Halászová, K., Kliment, M., Halva, J., eds. INFOS 2012: Zborník z VII. medzinárodnej vedeckej konferencie doktorandov a mladých vedeckých pracovníkov - Veda mladých 2012. Zuberec 27. - 29. 9. 2012. Nitra (Slovenská pol'nohospodárska univerzita v Nitre), pp. 183-190.

HALVA, J., KLIMENT. M. (2009). Vplyv presnosti digitálneho modelu reliéfu na modelovanie eróznej ohrozenosti. In Pešková, K., ed. Zborník z konferencie GIS Ostrava, 25.28.1.2009. Ostrava (VŠB, Technická univerzita Ostrava), pp. 1-5, [Online]. Dostupné na: http://gisak.vsb.cz/GIS_Ostrava/GIS_Ova_2009/sbornik/Lists/Papers/050.pdf [cit: 6-11-2020].

HANDY, S. L., NIEMEIER, D. A. (1997). Measuring accessibility: an exploration of issues and alternatives. Environment and Planning A, 29, 1175-1194. DOI: https:// doi.org/10.1068/a291175.

HORÁK, J., BURIAN, J., IVAN, I., ZAJÍČKOVÁ, L., TESLA. J., VOŽENÍLEK, V., FOJTÍK, D., INSPEKTOR, T., RYPKA, M. (2019). Prostorové simulační modelování dopravni dostupnosti. Praha (Česká geografická společnost).

HORÁK, J., IVAN, I., FOJTIK, D. (2015). Time of day dependency of public transport accessibility in the Czech Republic. Geoinformatics for Intelligent Transportation, 93108. DOI: https://doi.org/10.1007/978-3-319-11463-7_7.

HORNÁAK, M. (2005). Dostupnost' siete dial'nic a rýchlostných ciest v Slovenskej republike. Horizonty dopravy, 1, 31-34.

HORNÁK, M., KRAFT, S. (2015). Functional transport regions in Slovakia defined by passenger-car traffic flows. Mitteilungen der Osterreichischen Geographischen Gesellschaft, 157, 109-128. DOI: 10.1553/moegg157s109.

HORNAAK, M., PŠENKA, T., KRIŽAN, F. (2013). The competitiveness of the longdistance public transportation system in Slovakia. Moravian Geographical Reports, 21 (4), 64-75. DOI: https://doi.org/10.2478/mgr-2013-0021.

HORNÁK, M., TOLMÁČI, L, TOLMÁČI, A. (2019). Doprava. In Gurňák, D., ed. 30 rokov transformácie Slovenska. Bratislava (Univerzita Komenského v Bratislave), pp. 255-284.

HOYLE, B. S., KNOWLES, R. D. (1992). Modern transport geography. London (Belhaven Press).

HUDEČEK, T. (2010). Dostupnost v Česku v obdobi 1991 - 2001: vztah $k$ dojižd'ce do zaměstnání a do škol. Praha (Česká geografická společnost).

HUDEČEK, T., CHURAŇ, R., KUFNER, J. (2011). Dostupnost Prahy při využití silniční dopravy v období 1920 - 2020. Geografie - Sbornik ČGS, 116, 317-334.

CHEN, Y., JIN, F., LU, Y., CHEN, Z., YANG, Y. (2018). Development history and accessibility evolution of land transportation network in Beijing-Tianjin-Hebei region over the past century. Journal of Geographical Sciences, 28, 1500-1518. DOI: https:// doi.org/10.1007/s1 1442-018-1558-x. 
JÁNOŠÍKOVÁ, L. (2007). Optimálne umiestnenie staníc záchrannej zdravotnej služby z hl'adiska dopravnej dostupnosti. In Sborník př́spěvků z mezinárodní konference INFOTRANS 2007. Pardubice (Univerzita Pardubice), pp. 143-148.

JULIAO, R. P. (1999). Accessibility and GIS. In $39^{\text {th }}$ Congress of the European Regional Science Association: Regional cohesion and competitiveness in $21^{\text {st }}$ century Europe, August 23 - 27, 1999. Dublin (ERSA).

KOMORNICKI, T., STĘPNIAK, M. (2015). New investment projects in the road corridors and the improvement of the potential accessibility in Poland. Europa XXI, 28, 33-52. DOI: 10.7163/Eu21.2015.28.2.

KOTAVAARA, O., ANTIKAINEN, H., RUSANEN, J. (2011). Population change and accessibility by road and rail networks: GIS and statistical approach to Finland $1970-$ 2007. Journal of Transport Geography, 19, 926-935. DOI: https://doi.org/10.1016/ j.jtrangeo.2010.10.013.

KRAFT, S., MARADA, M., POPJAKOVÁ, D. (2014). Delimitation of nodal regions based on transport flows: case study of the Czech Republic. Quaestiones Geographicae, 33, 139-150. DOI: https://doi.org/10.2478/quageo-2014-0022.

KRIŽAN, F. (2007). Regionálna typológia územia Bratislavy na základe dostupnosti supermarketov a hypermarketov. Geografický časopis, 59, 373-286.

KUSENDOVÁ, D. (1996). Analýza dostupnosti obcí Slovenska. In Aktivity v kartografii 96. Zborník referátov. Bratislava (Kartografická spoločnost' SR a Geografický ústav SAV), pp. 29-49.

MAIER, K., DRDA, F., MULÍČEK, O., SÝKORA, L. (2007). Dopravní dostupnost funkčních městských regionů a urbanizovaných zón v České republice. Urbanismus a územni rozvoj, 10(3), 75-80.

MARADA, M., KVĚTOŇ, V., VONDRÁČKOVÁ, P. (2010). Doprava a geografická organizace společnosti v Česku. Praha (Česká geografická společnost).

MARTÍN, J. C., GARCÍA-PALOMARES, J. C., GUTIÉRREZ, J., ROMÁN, C. (2010). Efficiency and equity of orbital motorways in Madrid. Journal of Transport and Land Use, 3, 67-84. DOI: https://doi.org/10.5198/jtlu.v3i1.106.

MDaV SR (2018). Vývoj v doprave, poštách a výstavbe SR 2017. Bratislava, Žilina (Ministerstvo dopravy a výstavby SR, Výskumný ústav dopravný).

MDVRR (2015). Technické podmienky výpočet kapacit pozemných komunikácií. Sekcia cestnej dopravy a pozemných komunikácií. Bratislava (Ministerstvo dopravy výstavby a regionálneho rozvoja $\mathrm{SR})$.

MICHNIAK, D. (2003). Dostupnost' okresných miest na Slovensku. Geografický časopis, 55, 21-39.

MICHNIAK, D. (2014). Vybrané prístupy k hodnoteniu dopravnej dostupnosti vo vzt’ahu $\mathrm{k}$ rozvoju cestovného ruchu. Geografický časopis, 66, 21-38.

MICHNIAK, D., WIĘCKOWSKI, M., STĘPNIAK, M., ROSIK, P. (2015). The impact of selected planned motorways and expressways on the potential accessibility of the Polish -Slovak borderland with respect to tourism development. Moravian Geographical Reports, 23(1), 13-20. DOI: https://doi.org/10.1515/mgr-2015-0002.

MULIČEK, O., OSMAN, R., SEIDENGLANZ, D. (2015). Urban rhythms: A chronotopic approach to urban timespace. Time \& Society, 24, 304-325. DOI: https:// doi.org/10.1177/ 0961463X14535905.

MULÍCEEK, O., OSMAN, R., SEIDENGLANZ, D. (2016). Time-space rhythms of the city - The industrial and postindustrial Brno. Environment and Planning A, 48, 115-131. DOI: https://doi.org/10.1177/0308518X15594809.

NEMEŠKKAL, J., OUREDNÍČEK, M., POSPÍŠILOVÁ, L. (2020). Temporality of urban space: Daily rhythms of a typical week day in the Prague metropolitan area. Journal of Maps, 16, 30-39. DOI: https://doi.org/10.1080/17445647.2019.1709577.

O'SULLIVAN, D., MORRISON, A., SHEARER, J. (2000). Using desktop GIS for the investigation of accessibility by public transport: An isochrone approach. International Journal of Geographical Information Science, 14, 85-104. DOI: https://doi.org/ $10.1080 / 136588100240976$. 
PALÚCH, J., ČULÍK, K., KALAŠOVÁ, A. (2019). Analysis of the main causes of traffic problems in cities. Archives of Transport System Telematics, 12(4), 15-21.

PENÁZ, T. (2005). Zpřesnění liniového dopravního modelu sítě silničních komunikací pro účely analýzy dopravní dostupnosti. In Růžička, J., ed. Sborník z konference GIS Ostrava, 23.-26.1.2005. Ostrava (VŠB, technická univerzita Ostrava), pp. 1-10.

PEŠEK, O., KRAFT, S. (2019). Spatial mobility and current travel behaviour in the metropolitan hinterland. Geografický časopis, 71, 263-281. DOI: https://doi.org/10.31577/ geogrcas.2019.71.3.14.

POLIAK, M., POLIAKOVA, A., MRNIKOVA, M., ŠIMURKOVÁ, P., JAŚKIEWICZ, M., JURECKI, R. (2017). The competitiveness of public transport. Journal of Competitiveness, 9(3), 81-97. DOI: https://doi.org/10.7441/joc.2017.03.06.

SSC (2015). Celoštátne sčítanie dopravy v roku 2015, [Online]. Dostupné na: https:// www.ssc.sk/sk/cinnosti/rozvoj-cestnej-siete/dopravne-inzinierstvo/celostatne-scitaniedopravy-v-roku-2015.ssc [cit: 30-5-2020].

STEPNIAK, M., ROSIK, P. (2013). Accessibility improvement, territorial cohesion and spillovers: a multidimensional evaluation of two motorway sections in Poland. Journal of Transport Geography, 31, 154-163. DOI: https://doi.org/10.1016/j.jtrangeo. 2013.06.017.

ŚMIESZEK, M., LIANA, M., NYCZ, M. (2013). The size of public passenger transport and the number of passenger cars in Poland and Slovakia. Modern Management Review, 18, 145-158. DOI: https://doi.org/10.7862/rz.2013.mmr.35.

ŠVEDA, M., BARLÍK, P. (2018). Daily commuting in the Bratislava metropolitan area: Case study with mobile positioning data. Papers in Applied Geography, 4, 409-423. DOI: https://doi.org/10.1080/23754931.2018.1540357.

TAYLOR, Z., CIECHAŃSKI, A. (2020). Ownership transformation and FDI among national carriers operating road passenger transport services in the Visegrád Group (V4) countries. Geografický časopis, 72, 81-102. DOI: https://doi.org/10.31577/geogrcas. 2020.72.1.05.

TOLMÁČI, L. (2002). Dostupnost' miest Slovenska. Regionálnogeografické štúdie, 1, 3-66.

TYKKYLÄINEN, M. (1981). Accessibility in the provinces of Finland. Fennia, 159, 361396. DOI: https://doi.org/10.11143/fennia.9158.

VITURKA, M. (1981). Vztah sídelní struktury a silniční dopravy. Sborník Československé geografické společnosti Praha, 86, 28-37.

WARAKOMSKA, K. (1992). Zagadnienie dostępności w geografii transportu. Przegląd Geograficzny, 64, 67-76.

WEBSTER, R., OLIVER, M. A., MUIR, K. R., MANN, J. R. (1994). Kriging the local risk of a rare disease from a register of diagnoses. Geographical Analysis, 26, 168-185. DOI: https://doi.org/10.1111/j.1538-4632.1994.tb00318.x.

WIŚNIEWSKI, S. (2018). Relations between theoretical and real-time accessibility for inter-regional, intra-regional and intra-urban car journeys: The example of Poland. Bulletin of Geography. Socio-economic Series, 41, 45-58. DOI: https://doi.org/10.2478/bog $-2018-0025$.

Richard Stanek, Dagmar Kus endová, Marcel Hor $\check{n} a ́ k$

\section{SLOVAKIA'S TERRITORY ACCESSIBILITY MODEL DESIGN METHODOLOGY BASED ON DAILY CAR-TRAFFIC INTENSITY USING GEOINFORMATION TOOLS}

Accessibility analysis is one of the most frequent topics in transport research. Geographic information systems (GIS) currently offer several options for a traffic accessibility analysis. This paper focuses on the description of the process of creating a model of transport accessibility by individual car transport in Slovakia. The paper focuses merely on 
the methodology of several spatial and non-spatial data sets integration in order to create a network model enabling to perform a network analyses. Emphasised is the factor of cartraffic intensity variation during the day with four variations of the traffic intensity mode as follows:

1.application of the average number of vehicles in the road section per 24 hours - an average daily car-traffic intensity;

2. night car-traffic intensity;

3. peak-time car-traffic intensity;

4. car-traffic intensity between traffic peaks - a traffic-saddle intensity.

The model itself can only be accurate to the extent that the input data is accurate. The basis for the accessibility model designed by the authors is the reference network of roads and local roads provided by the Department of the Road Database of the Slovak Road Administration, which is suitable both from the attribute point of view and also from the point of view of geometric and topological accuracy. This layer was further modified by a series of geoinformation tools in the GIS environment, in order to achieve the highest possible accuracy of the model. Figures $1-3$ show the process of delimitation of built-up areas and sections of roads located here.

The intensity of car-traffic in Slovakia is monitored by the traffic censuses performed in 5-year intervals and recorded as the number of vehicles per day on individual road-network sections. In order to obtain traffic intensity values for each section of the reference network, it was necessary to calculate values for the sections that are not covered by the census. This step was performed by a spatial interpolation method and subsequently the values from the aster data set were transferred to the reference network (Figs. 5 and 6). After substituting the traffic intensity value into each segment of the modified reference network, the values were calculated per lane.

The values of the car-traffic intensity for an individual day period were subsequently determined according to the curve of the approximated course of traffic intensity during the day (Fig. 7). Subsequently, an exponential regression analysis was used, where the traffic intensity was entered as an independent variable and thus determined the values for speed and the ratio of the maximum speed on a given road, respectively (Fig. 8). In this way, all four accessibility modes were created based on the changing traffic intensity. Figs. 9 and 10 show the differences between the individual modes of time accessibility in the city of Bratislava. 
